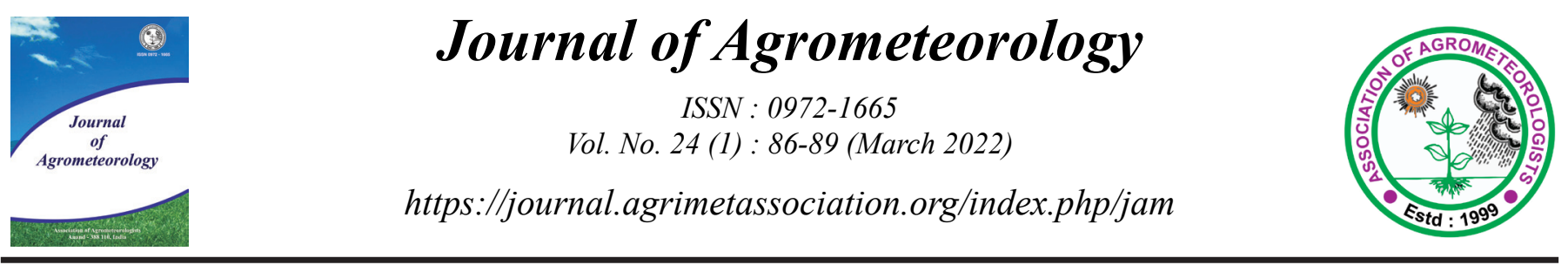

Short Communication

\title{
Influence of prevailing weather conditions on incidence of thrips on different solanaceous vegetables cultivation
}

\section{AMIT KUMAR ${ }^{1}$, TAMOGHNA SAHA ${ }^{1 *}$, NITHYA CHANDRAN ${ }^{2}$, RACHANA R.R. ${ }^{3}$ and SANTOSH KUMAR $^{4}$}

${ }^{1}$ Dept of Entomology, BAU, Sabour, Bhagalpur, India

${ }^{2} I C A R-I A R I$, New Delhi, India,

${ }^{3} I C A R-N B A I R$, Bengaluru, India

${ }^{4}$ Dept of Plant Pathology, BAU, Sabour, Bhagalpur, India

*Corresponding author email : tamoghnasaha1984@gmail.com

The solanaceous family of vegetables including tomatoes (Solanum lycopersicum), brinjal (eggplant) (Solanum melongena), potatoes (Solanum tuberosum), capsicum and chilli (Capsicum spp) species holds much economic importance. These crops are grown throughout the year in most parts of the India. The key pests of solanaceous vegetables are mainly biting type or sucking types viz., fruit borer, beetles, leafhopper, aphids, bugs, thrips, whitefly, mites, and leaf miner (Ahmad et al., 2019). Among the insect pests, thrips (Thysanoptera: Thripidae) is an important insect pest with a worldwide distribution. Infestation caused by thrips is easily perplexed with feeding damage from broad mites. In severe infestation, the tender leaves and buds become brittle, followed by necrosis of plant tissue and complete defoliation (Kumar et al., 2013). The estimated yield losses in chilli due to thrips ranged from 50 to 90 per cent. The direct injury and the virus disease transmitted by thrips result in discoloration of tomato fruits and thus lower the quality of the fruits with yield losses up to 23.7 per cent (Kagezi et al., 2001). Therefore, population dynamics is an important tool for the developing pest management strategies against this pest. Periods of no incidence, initiation of incidence, low incidence, peak incidence etc. carry important information to decide the time for adoption of management tactics. Therefore, correlations between thrips incidence and the weather parameters i.e. temperature, humidity, rainfall and rainy days have been worked out by using SPSS 16 statistical software for management strategies.

The experiment was conducted during Kharif and Rabi seasons of 2018-19 and 2019-20 at the Vegetable Research Farm, Bihar Agricultural University, Sabour, Bhagalpur. Weather data were obtained from automatic weather station installed approx. 150 meters away from the experimental site. Nursery of the test variety of Chilli (Arka Lohit) and brinjal (muktakeshi) were raised at the experimental site in first week of July 2018 and 2019, while the nursery of tomato (Kashi Vishesh) in the first week of October, 2018 and 2019. Twenty-five days old seedlings of brinjal and chilli crops were transplanted in the last week of July, 2018 and 2019 and tomato in the third week of November, 2018 and 2019 following spacing pattern of $60 \times 45 \mathrm{~cm}$. The experimental area used standard agronomic practices for cultivation excluding pesticide application. The observations of thrips were done at 7 days interval (Standard meteorological weeks) from 15 days after transplanting (DAT) up to harvesting of the crop. The population of thrips on fully opened leaves was recorded from thirty (30) randomly selected plants of brinjal and tomato and three leaves (One from the top, middle and lower canopy) from each plant were taken for recording the thrips population. As far as chili plant is concerned, thrips were collected from terminal leaves. Both nymphs and adults population was counted early in the morning before 8.00 am when the pests were not much active. Thrips were collected by Beat Method selected leaves tapped on a white paper board $(30 \times 30 \mathrm{~cm})$ and gathered with a fine hair brush. Gathered thrips were transferred to a vial containing 70 per cent ethanol marked with the date, plot and crops to count the population.

A simple correlation coefficient was calculated between meteorological parameters such as atmospheric temperature (maximum and minimum), relative humidity (morning and evening), rainfall and sunshine hours and thrips population. Multiple regressions analysis was also worked out taking meteorological parameters as an independent variable to know the combined effects

Article info - DOI: https://doi.org/10.54386/jam.v24i1.784

Received: 10 February 2021; Accepted: 29 December 2021; Published online: 11 February 2022

This work is licenced under a Creative Common Attribution4.0International licence@Author(s),Publishing right@ Association of Agrometeorologists 


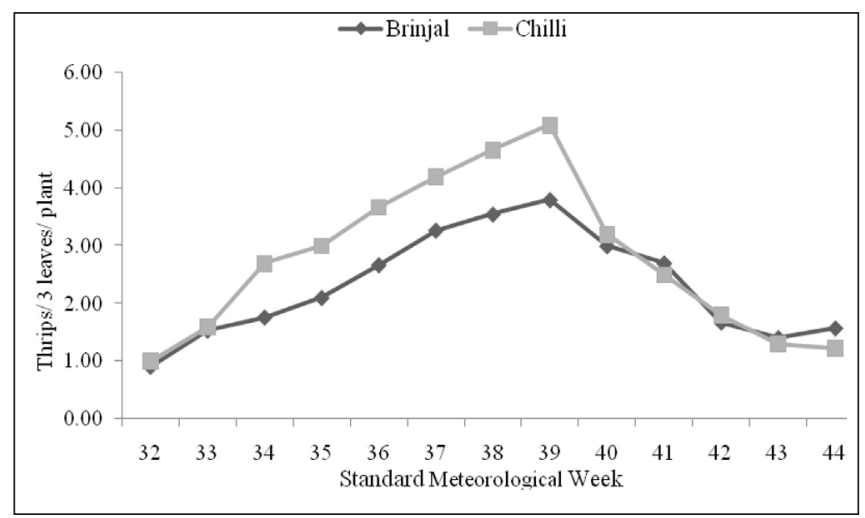

Fig 1: Mean incidence of thrips on brinjal and chilli during kharif, 2018-19 and 2019-20

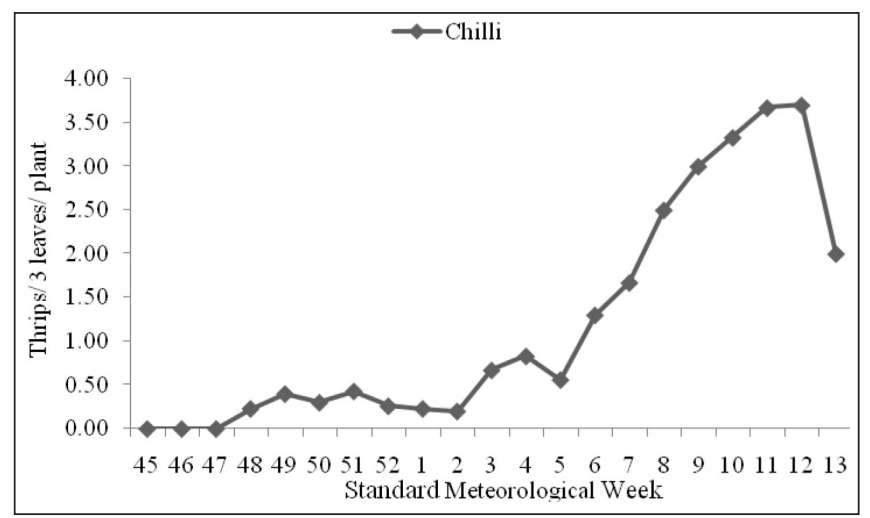

Fig 2: Mean incidence of thrips on tomato during rabi season of 2018-19 and 2019-20

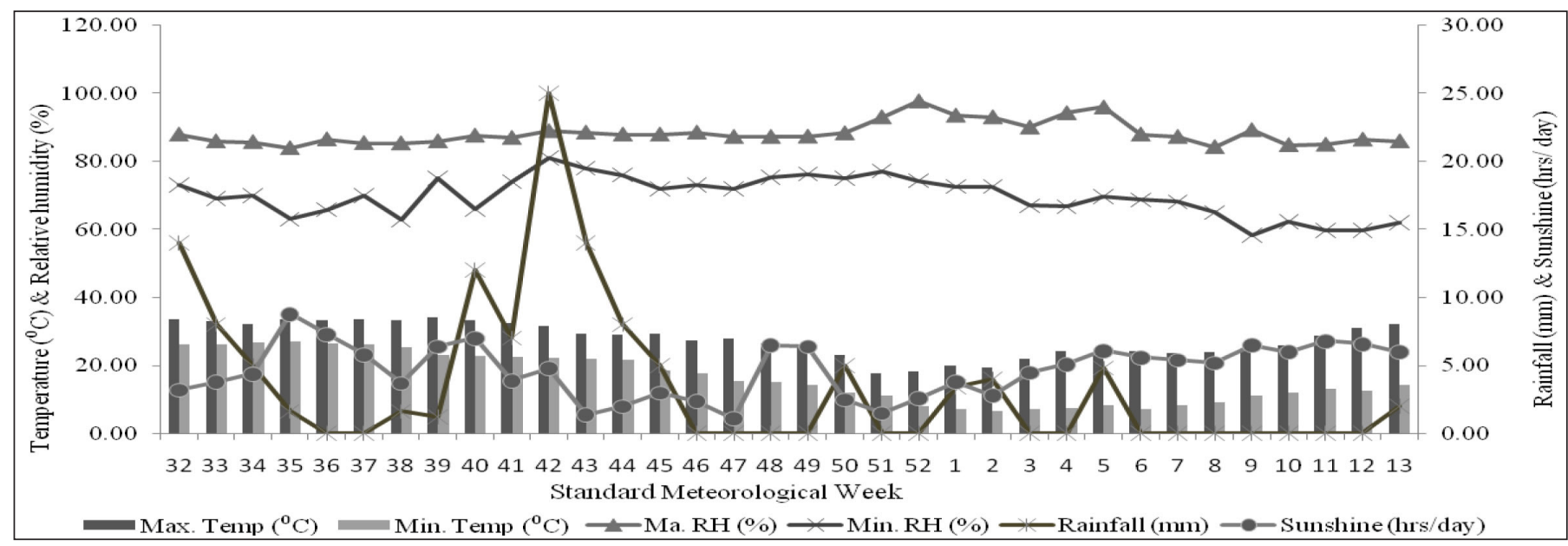

Fig 3: Prevailing weather conditions during crop growing period of kharif and rabi 2018-19 and 2019-20

of all these factors leading to upsurge in thrips population.

\section{Incidence of brinjal thrips during kharif season}

Three thrips species; Thrips palmi, Frankliniella schultzei and Scirtothrips dorsalis were identified from brinjal crop. It is revealed from the figure (Fig. 1) that the incidence of thrips was first appeared ( 0.90 thrips $/ 3$ leaves) in $32^{\text {nd }}$ standard meteorological week (SMW) and and it reached at peak (3.80 thrips/3 leaves) during $39^{\text {th }}$ SMW in both the years (Fig. 1), when mean maximum and minimum temperature, mean relative humidity (morning and evening), rainfall and sunshine hrs were 34.2 and $23.0{ }^{\circ} \mathrm{C}, 86$ and 75 per cent, $1.2 \mathrm{~mm}$ and $6.40 \mathrm{hrs} /$ day, respectively. The thrips population ranged from 0.90 to 3.80 thrips/3 leaves in Brinjal crop during kharif season, 2018-19 and 2019-20. The correlation study showed that the population of thrips exhibited significant positive association with maximum temperature $\left(\mathrm{r}=0.54^{*}\right)$, which indicates thrips population increases with the increase in temperature (Table 1). On the other hand, most of the weather parameters like minimum temperature $(\mathrm{r}=-0.02)$, maximum and minimum relative humidity $(\mathrm{r}=-0.46 ;-0.39)$ had no significant effect on the population of thrips. Rainfall showed significant negative correlation $(r=-0.60 *)$ on the population of thrips at $5 \%$ level of significance. However, sunshine hours showed only positive impact $(\mathrm{r}=0.49)$ on thrips population. The present study revealed that, the population of thrips had considerable positive effect with maximum temperature, whereas, significant negative impact with rainfall. The multiple regression equation indicated that the weather parameters were found to contribute around 83 per cent (Table 2) impact on population of thrips in brinjal crop when acted together $\left(\mathrm{R}^{2}=0.83\right)$. The present findings are in accordance with the reports of Rashid et al. (2013) who found that the average temperature recorded had a significant positive effect on population of thrips. Moanaro and Jaipal (2016) also reported that a strong significant positive correlation existed between the number of thrips and maximum temperature, whereas, significant negative correlation between thrips population and rainfall.

\section{Incidence of chilli thrips during Kharif season}

Two thrips species; Scirtothrips dorsalis and Thrips palmi were identified from chilli crop. The thrips infestation commenced in the $32^{\text {nd }}$ standard meteorological week with an average population of 1.00/ 3 leaves (Fig. 1) where maximum and minimum temperatures, maximum and minimum relative humidity and rainfall were $33.6^{\circ} \mathrm{C}, 26.3^{\circ} \mathrm{C}, 88$ and 73 per cent and rainfall $14 \mathrm{~mm}$, respectively (2018-19 and 2019-20) (Fig. 3) and the thrips population ranged from 1.00 to 5.10 thrips $/ 3$ leaves in chilli crop during kharif season. The correlation study revealed that the population of thrips had significant positive correlation (significant at $\mathrm{p}=0.05)$ with maximum temperature $\left(\mathrm{r}=0.64^{*}\right)$ and sunshine hrs $\left(\mathrm{r}=0.59^{*}\right)$, while minimum temperature showed non- 
Table 1: Correlation between the thrips population (Number of thrips/ 3 leaves/ plant) and weather parameters

\begin{tabular}{lccc}
\hline Weather parameters & Brinjal & Chilli & Tomato \\
\hline Maximum temperature & $0.54^{*}$ & $0.64^{*}$ & $0.43^{*}$ \\
Minimum temperature & -0.02 & 0.23 & -0.04 \\
Maximum relative humidity & -0.46 & $-0.61^{*}$ & $-0.54^{* *}$ \\
Minimum relative humidity & -0.39 & -0.49 & $-0.90^{* *}$ \\
Rainfall & $-0.60^{*}$ & $-0.69^{* *}$ & -0.38 \\
Sunshine & 0.49 & $0.59^{*}$ & $0.67^{* *}$ \\
\hline
\end{tabular}

*Significant at 5\% level, **Significant at $1 \%$ level

Table 2: Regression analysis between the thrips population and weather parameters

\begin{tabular}{lll}
\hline Crop & Regression equation & $R^{2}$ \\
\hline Brinjal & $\mathrm{Y}=4.944+0.358 \mathrm{X}_{1}-0.380 \mathrm{X}_{2}-0.033 \mathrm{X}_{3}-0.023 \mathrm{X}_{4}-0.077 \mathrm{X}_{5}+0.023 \mathrm{X}_{6}$ & 0.83 \\
Chilli & $\mathrm{Y}=5.186+0.440 \mathrm{X}_{1}-0.335 \mathrm{X}_{2}-0.096 \mathrm{X}_{3}-0.003 \mathrm{X}_{4}-0.109 \mathrm{X}_{5}+0.096 \mathrm{X}_{6}$ & 0.77 \\
Tomato & $\mathrm{Y}=25.797-0.169 \mathrm{X}_{1}+0.092 \mathrm{X}_{2}-0.096 \mathrm{X}_{3}-0.198 \mathrm{X}_{4}-0.027 \mathrm{X}_{5}+0.166 \mathrm{X}_{6}$ & 0.90 \\
\hline
\end{tabular}

Where, $\mathrm{Y}=$ Number of thrips, $\mathrm{X}_{1}=$ Maximum temperature $\left({ }^{\circ} \mathrm{C}\right), \mathrm{X}_{2}=$ Minimum temperature $\left({ }^{\circ} \mathrm{C}\right), \mathrm{X}_{3}=$ Morning relative humidity $(\%), \mathrm{X}_{4}=$ Evening relative humidity $(\%), \mathrm{X}_{5}=$ Rainfall $(\mathrm{mm}), \mathrm{X}_{6}=$ Sunshine (hrs/day)

significant positive correlation $(\mathrm{r}=0.23)$ with the population of thrips (Table: 1). However, maximum relative humidity $(\mathrm{r}=-0.61 *)$ and rainfall $(\mathrm{r}=-0.69 * *)$ had strong negative correlation with thrips population. Minimum relative humidity exhibited non significant negative correlation $(r=-0.49)$ with the population of thrips. The multiple regression analysis revealed that weather factors was found to be most influencing factor, which contributed $\left(\mathrm{R}^{2}=0.77\right)$ 77 per cent influence on population of thrips in chilli crop when acted together (Table 2). The present finding are in collaboration with the earlier results of Kumar et al. (2019), who reported that the thrips population in chilli was first noticed during September and attained its peak during the $3^{\text {rd }}$ week of October. The correlation study showed that the thrips population had significant positive association with maximum temperature. The present findings are also in line with the earlier findings of Pathipati et al. (2014), who also observed that thrips population had a positive correlation with maximum temperature.

\section{Incidence of tomato thrips during rabi season}

Two thrips species were identified namely T. palmi and T. tabaci from tomato. The data on seasonal incidence of thrips presented in fig. 2 revealed that the incidence of thrips was observed throughout the last week of November ( $48^{\text {th }}$ standard week) with a mean population of 0.23 thrips $/ 3$ leaves where maximum and minimum temperature was $26.5{ }^{\circ} \mathrm{C}$ and $15.0{ }^{\circ} \mathrm{C}$, respectively, with mean relative humidity (morning and evening) and sunshine hours was 87,75 per cent and 6.50 hrs/day, respectively (Fig. 3). The population of thrips reached at peak in $11^{\text {th }}$ and $12^{\text {th }}$ standard meteorological week with 3.67 and 3.70 thrips/leaves (Fig. 2) and there after the population was declined. The experimental results revealed that maximum temperature $\left(r=0.43^{*}\right)$ and sunshine hrs $(r$ $\left.=0.67^{* *}\right)$ showed considerable positive impact on the population of thrips infesting tomato leaves, whereas, maximum and minimum relative humidity $\left(\mathrm{r}=-0.54 * *,-0.90^{* *}\right)$ had direct negative effect on the population of thrips (Table. 1). The other parameters like minimum temperature $(r=-0.04)$ and rainfall $(r=-0.38)$ has no impact on the population oscillation on thrips population. The regression equation indicated that all the weather factors like maximum and minimum temperature, maximum and minimum relative humidity, rainfall and sunshine hrs showed 90 per cent effect $\left(\mathrm{R}^{2}=0.90\right)$ on the population of thrips (Table: 2$)$. The present findings are supported with earlier findings of Naresh et al. (2017) who reported that maximum and minimum temperature had positive impact on the incidence of thrips. Akashe et al. (2016) also reported that thrips population was positively correlated with maximum temperature while it was negatively correlated with morning and evening relative humidity and rainfall.

It is concluded that the population of thrips had significant positive correlation with maximum temperature in both the seasons and it indicates that thrips population increases with the increase in temperature, whereas, the maximum and minimum relative humidity was negatively associated (no significant effect on the population of thrips) with all the three vegetable crops but highly significant during Rabi season. Sunshine hours had a significant positive impact on the population of thrips.

Conflict of Interest Statement: The author(s) declare(s) that there is no conflict of interest.

Disclaimer: The contents, opinions and views expressed in the research article published in Journal of Agrometeorology are the views of the authors and do not necessarily reflect the views of the organizations they belong to.

Publisher's Note: The periodical remains neutral with regard to jurisdictional claims in published maps and institutional affiliations.

\section{REFERENCES}

Ahmad, T., Danish, S., Woldu, L., Brhane, T., Tsegay, Y. and Haile, Y. (2019). Allure of insect pest and diseases among three solanaceous crops viz. tomato, chilli and brinjal in Hamelmalo Agricultural College. Afr. J. Agric. Res., 14 (19): 843-849. 
Akashe, V.B., Jadhav, J.D., Bavadekar, V.R., Pawar, P.B. and Amrutsagar, V. M. (2016). Forewarning models for sunflower thrips (Thrips Palmi Karny) in western Maharashtra scarcity zone. J. Agrometeorol., 18(1):68-70.

Kagezi, E.L., Kyamanywa, S., Akemo, M.C., Luther, G. and Erbaugh M. 2001. Damage-yield relationships of major pests of tomatoes in central Uganda. Integrated Pest Management Collaborative Research Support Program Annual Report, 8: 259-262.

Kumar, D., Sharma, K.R. and Raju, S.V.S. (2019). Influence of weather factors on the population dynamics of chilli thrips, Scirtoithrips dorsalis (Hood) and aphid, Aphis gossypii (Glover). J. Exp. Biol. Agric. Sci., 7(3): 289-294.

Kumar, V., Kakkar, G. and McKenzie, C.L. (2013). An overview of chilli thrips, Scirtothrips dorsalis (Thysanoptera: Thripidae) Biology, Distribution and Management. Intech Open Science, Chapter 3: dx.doi.org/10.57772/55045.
Moanaro and Jaipal, S.C. (2016). Influence of weather parameters on population dynamics of thrips and mite on summer season cowpea in Eastern Plateau and hill region of India. J. Agrometeorol., 18 (2): 296-299.

Naresh, T., Rao, A.R., Krishna, T.M. and Devaki, K. (2017). Seasonal incidence and population dynamics of thrips in groundnut during rabi season. Curr. Biotica, 10(4): 280289.

Pathipati, V.L., Vijayalakshmi, T. and Naram, N.L. (2014). Seasonal incidence of major insect pests of chilli in relation to weather parameters in Andhra Pradesh. Pest Manag. Hortic. Ecosyst., 20(1): 36-40.

Rashid, M.H., Khatun, M.J., Mahfuz, M.S., Dash, C.K. and Hussain, M.A. (2013). Seasonal fluctuation of insect pests of Brinjal at Agricultural research station, Ranjpur. Int. J. Expt. Agric., 3(1): 4-8. 